\title{
Hunting on the coast: An image gallery of Rompecráneos
}

\author{
Daniela Soledad Cañete Mastrángelo
}

Consejo Nacional de Investigaciones Científicas y Técnicas, Instituto Nacional de Antropología y Pensamiento Latinoamericano, 3 de Febrero 1378, CABA, Argentina. Email: danielasol.cm@gmail.com

\begin{abstract}
:
The Rompecráneo is a special kind of lithic artifact which was, presumably, involved in the capture of pinnipeds carried out along the Patagonian coast of Argentina during prehistoric times. Recent papers had offered some information about their morphology but up to now they are poorly studied. In order to offset this situation in a previous work we addressed their role in hunting technics developed at the archaeological locality of Punta Entrada (Santa Cruz, Argentina). This allowed us to propose that rompecráneos were used in combination with spears when hunting on the coast. With the aim of expanding this information, here we present an image gallery of some rompecráneos recovered there. Two of these pieces share a similar morphology but were made of different lithic raw materials. The other one has the appearance of a bola stone but its weight is higher than other bola stones in Patagonia. That is why it is considered a different kind of artifact. The importance of studying these kinds of artifacts is that they have the potential of providing information about the way people interacted with the different resources (biotic and abiotic) in the past so that a better understanding of human behavior can be developed.
\end{abstract}

Keywords: rompecráneos; lithic technology; Pinnipeds; Patagonia; ground stone

Little is known about rompecráneos which are a kind of lithic artifact allegedly linked to the onshore capture of pinnipeds during prehistoric times. These artifacts have been recovered mainly along the Patagonian coast of Argentina and only a small quantity of them was found inland, highlighting its connection to the coast and the resources found there (Moreno 2008) and also between these two environments. According to previous investigations, it can be said that rompecráneos are a kind of bola stone with different finish. Also, they were used in a different way (Moreno 2008; Moreno et al. 2000). Rompecráneos have a rough finish, a pronounced groove in the middle of the piece and a prepared base where a wooden handle could be placed. If this is correct, these artifacts would have been used by hitting in a similar way sealer employed seal clubs in historical times (Mayorga 2017). Here we present images of these artifacts and share them with colleagues researching in similar contexts. The pieces shown in this image gallery were recovered in the archaeological locality of Punta Entrada (Santa Cruz river mouth, Santa Cruz province, Argentina) (Figure 1). This locality is characterized by high amounts of open air archaeological material concentrations in which pinnipeds (Arctocephalus australis and Otaria flavescens) are the main prey among the ISSN: 2055-0472. URL: http://journals.ed.ac.uk/lithicstudies/ 
zooarchaeological remains. These are gregarious sea mammals that spend time in the sea but also on the shore, particularly in the reproductive season. During that time, pinnipeds can become very aggressive (Cappozzo 1995; Pérez-Álvarez et al. 2013; Vaz-Ferreira et al. 1984). Since hunter-gatherers did not develop boat technology in this area, hunting must have taken place on the land with particular hunting strategies, as it has been proposed by Cañete Mastrángelo (2019).

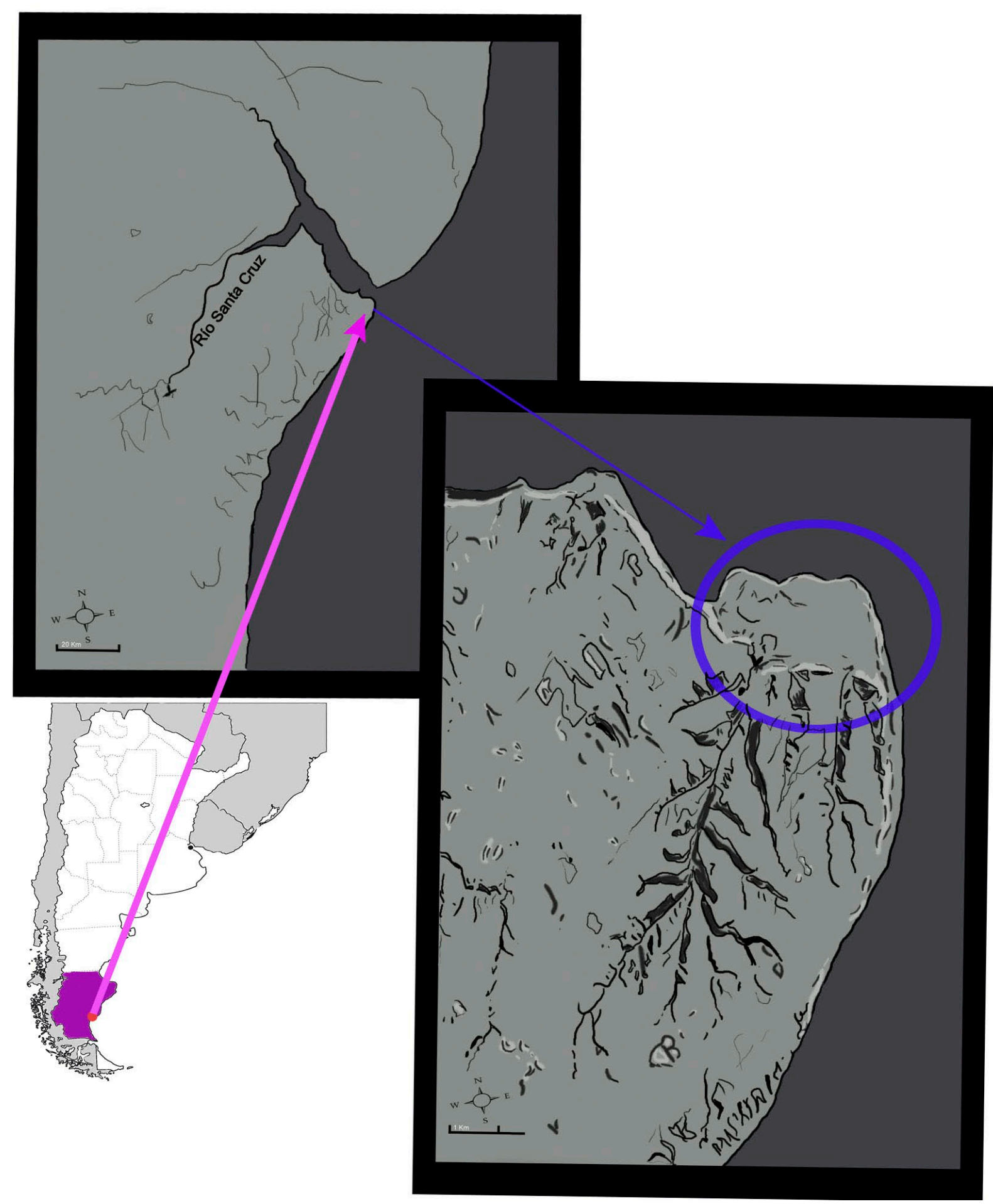

Figure 1. Geographic location of Punta Entrada. [Download a high resolution version of this image here.] 
It is worth noting that Arctocephalus australis females can reach $50 \mathrm{~kg}$ of weight while males can weight $160 \mathrm{~kg}$ and Otaria flavescens are bigger animals which can reach $170 \mathrm{~kg}$ (females) and $400 \mathrm{~kg}$ of weight (males) (Cappozzo 1995). This would have required the development of appropriate strategies and weapons that would allow hunter-gatherers to capture and kill that kind of animals. Thus, studying the weaponry involved in this activity is important to have a better knowledge of the way people interacted with animals and environment in the past.

The archaeological record of Punta Entrada is dated back to late Holocene (Muñoz et al. 2009) and so can be assumed with rompecráneos. In this image gallery three pieces are presented (Figures 2, 4, and 6). Two of them have the characteristic aspect described above (Figures 2, 3, 4 and 5). The other one looks like a bola stone (it is a spheroid without a prepared base) but its size and weight (Figures 6,7 and 8) is higher suggesting it was used in a different weaponry system from boleadoras and closer to the way rompecráneos did. Considering it weighs more than $1 \mathrm{~kg}$, it is unlikely that this piece was used as a throwing weapon. As it has been said, the study of rompecráneos is important to coastal archaeology as they can give information about the way people captured pinnipeds, the hunting strategies involved and the space organization. This information can also contribute to the understanding of human behavior in coastal environments.

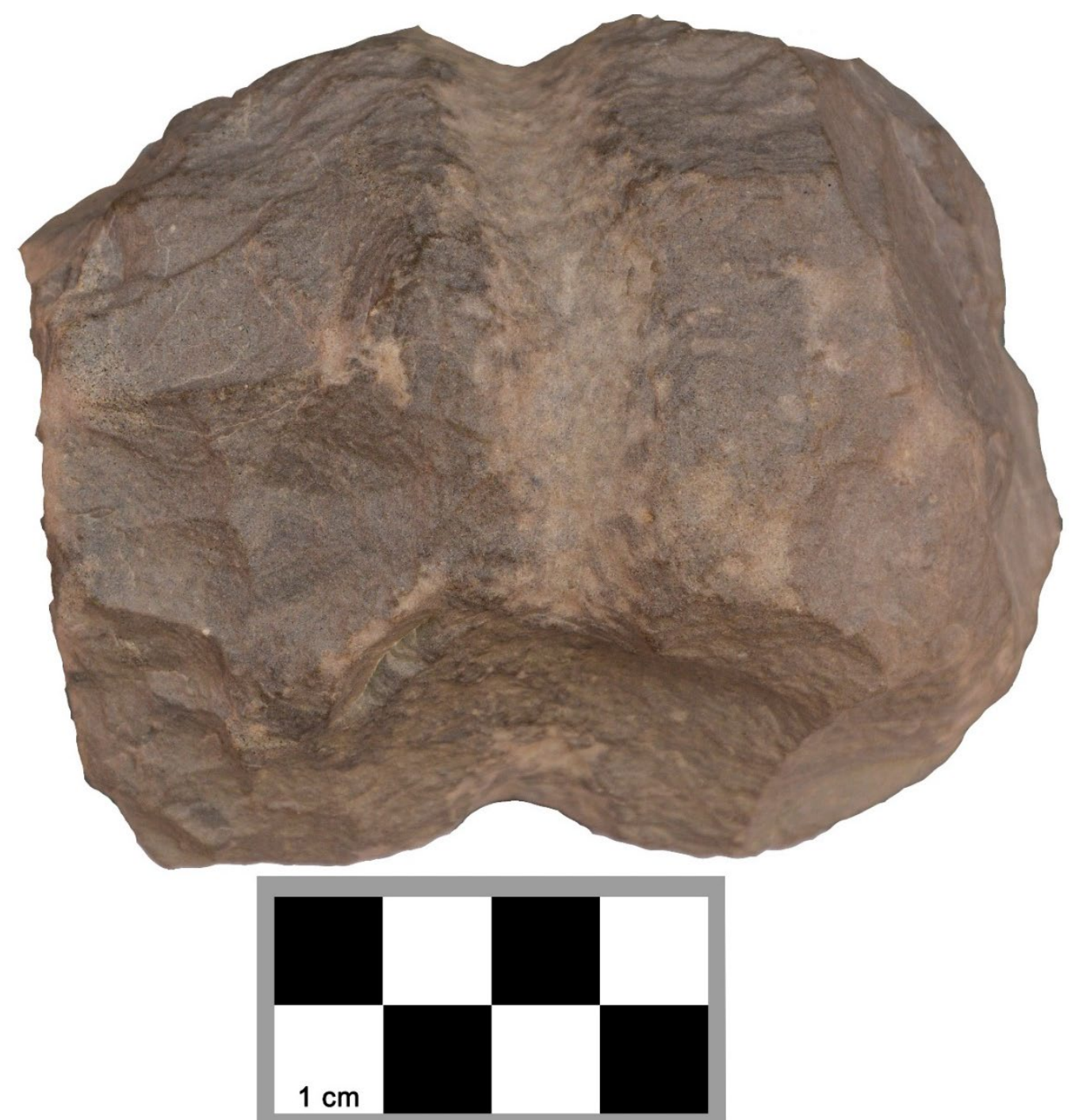

Figure 2. Rompecráneo made of andesite. The base can be seen in the lower part of the image. Weight: 593 g. [Download a high resolution version of this image here.] 

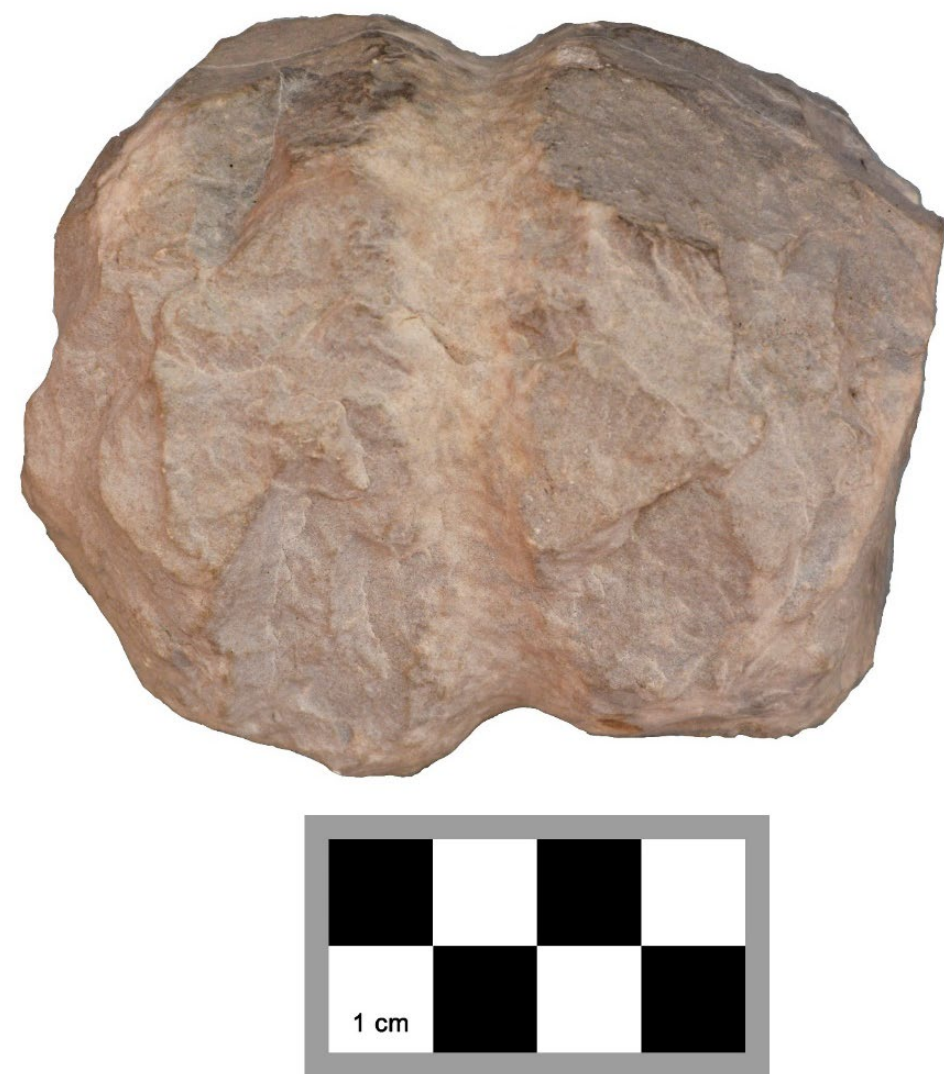

Figure 3. Different view of the rompecráneo shown in Figure 2. [Download a high resolution version of this image here.]
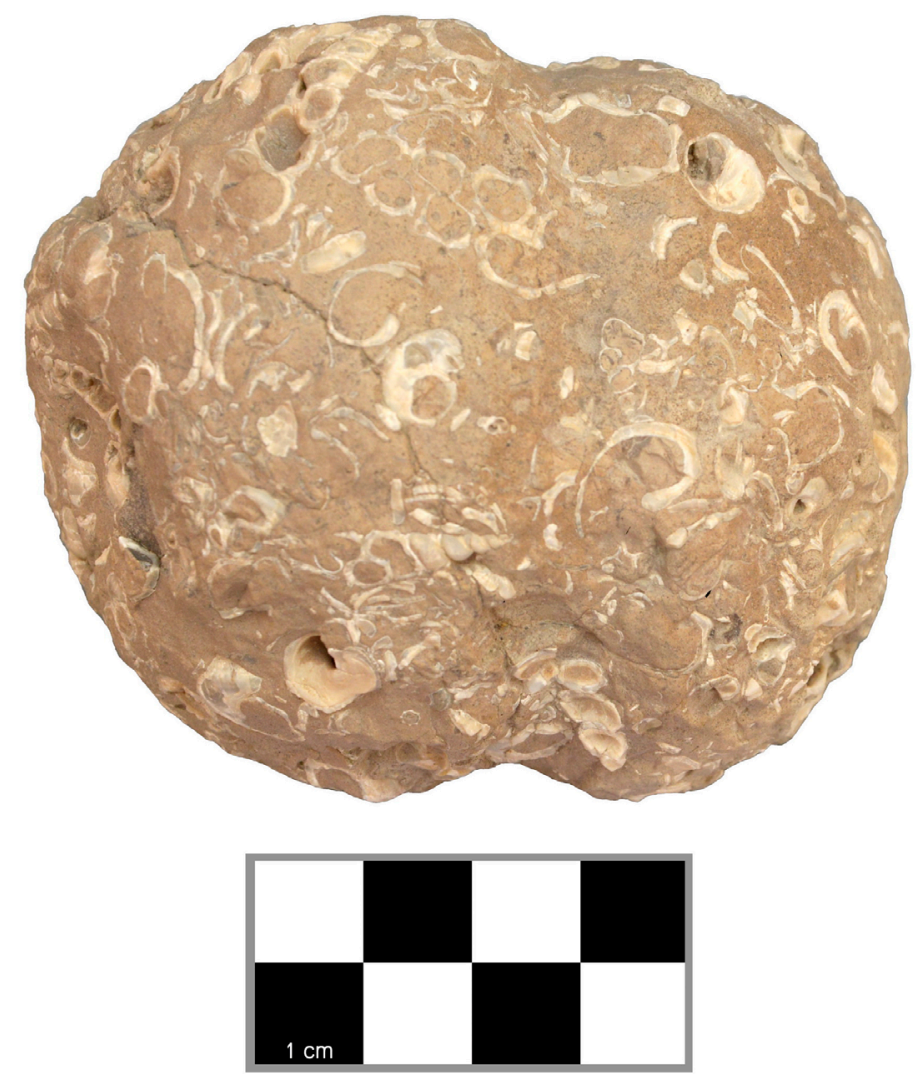

Figure 4. Rompecráneo made of coquina. The base can be seen in the lower part of the image. Weight: $421 \mathrm{~g}$. [Download a high resolution version of this image here.] 


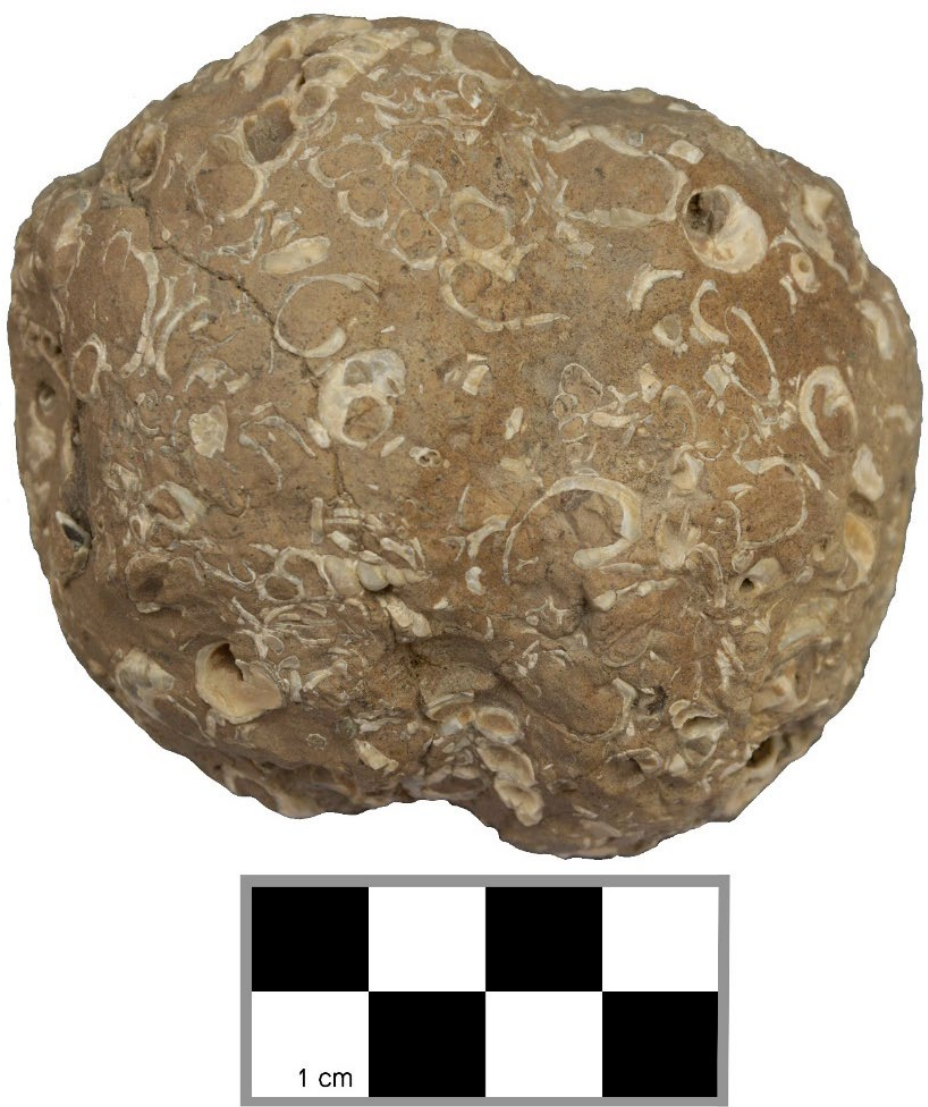

Figure 5. Different view of the rompecráneo shown in Figure 3. [Download a high resolution version of this image here.]

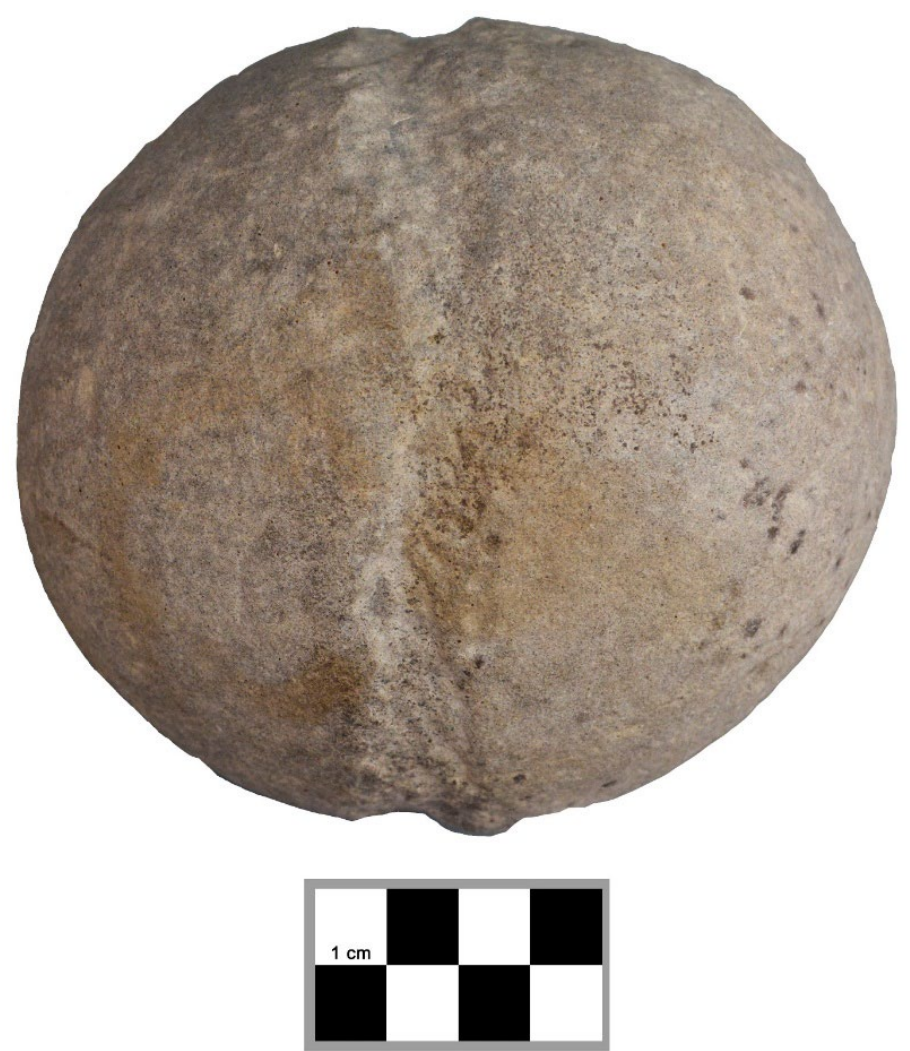

Figure 6. Bola stone made of andesite. Weight:1.476 kg. [Download a high resolution version of this image here.] 


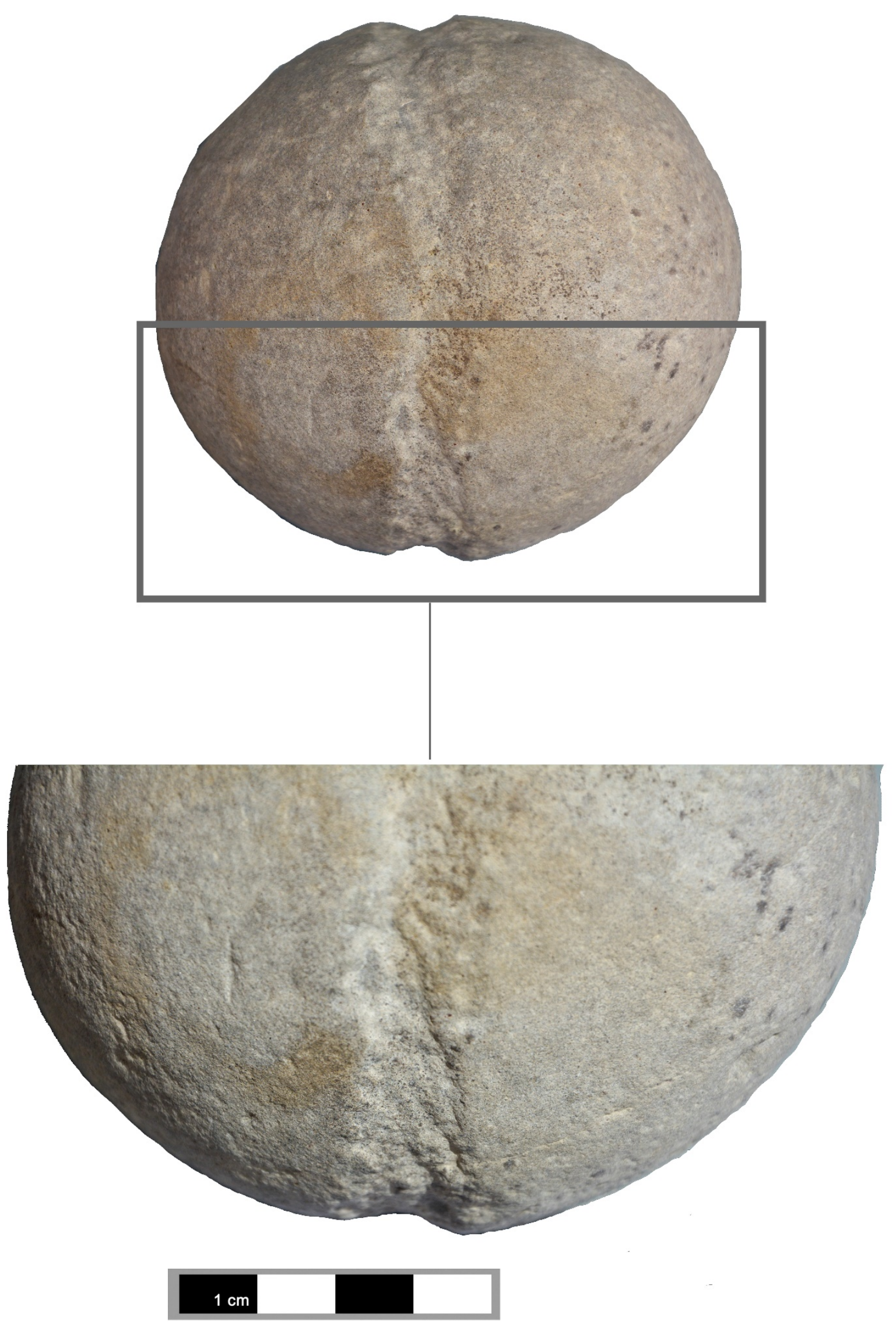

Figure 7. Detail of the groove of the bola stone shown in Figure 6. [Download a high resolution version of this image here.] 


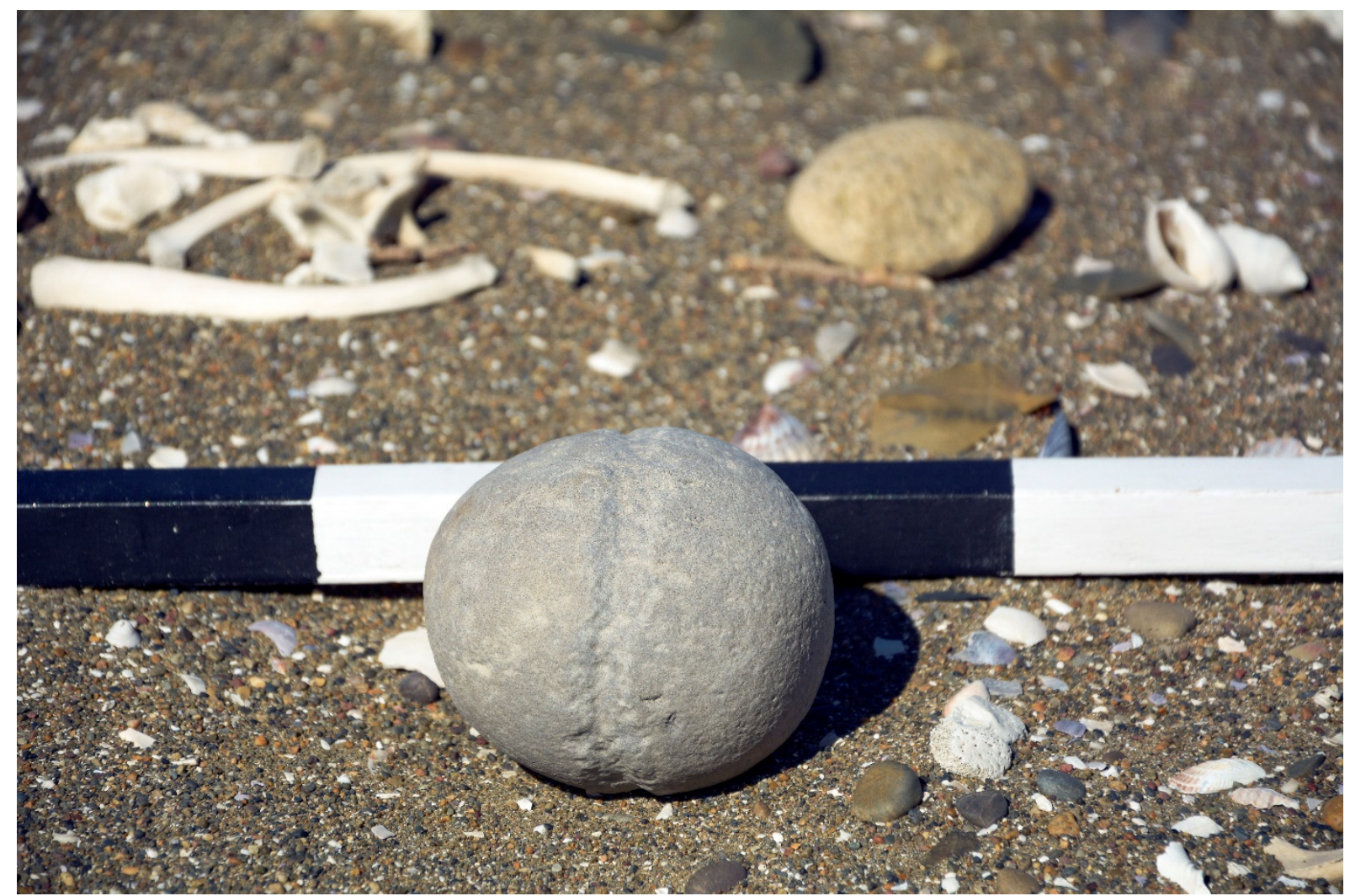

Figure 8. Context of recovery of bola stone presented in Figure 6. [Download a high resolution version of this image here.]

\section{References}

Cañete Mastrángelo, D.S. 2019, Decisiones tecnológicas, técnicas de caza y uso del espacio en la Patagonia Meridional. Aportes desde la tecnología lítica de Punta Entrada y Parque Nacional Monte León. Doctoral Thesis at Universidad de Buenos Aires, Buenos Aires, Argentina, 496 p. (in Spanish) ("Technological decisions, hunting techniques and use of the space in southern Patagonia. Contributions from the lithic technology of Punta Entrada y Parque Nacional Monte León”)

Cappozzo, H.L. 1995, Comportamiento reproductivo en dos especies de Otáridos de América del Sur. Doctoral Thesis at Departamento de Ciencias Naturales y Exactas, Universidad de Buenos Aires, Buenos Aires, 147 p. (in Spanish) ("Reproductive Behaviour in Two Species of Otariade from South America”)

Mayorga, M.Z. 2017, Actividad lobera temprana en la Patagonia Oriental: caza de mamíferos marinos. Revista Iberoamericana de Viticultura, Agroindustria y Ruralidad, 4(11): 3151. (in Spanish) ("Early Sealing Activities in the Eastern Patagonia: Hunting of Marine Mammals”)

Moreno, J.E. 2008, El uso indígena de la costa patagónica central en el período tardío. Fondo Editorial Provincial. Secretaría de Cultura de Chubut, Rawson, 120 p. (in Spanish) ("The Indigenous Use of the Central Patagonian Coast in the Late Period”) 
Moreno, J. E., Castro, A. \& Pepe, F. 2000, El rompecráneo: un artefacto probablemente destinado para la caza de pinnípedos en la costa de Patagonia continental. In Desde el país de los gigantes. Perspectivas arqueológicas en Patagonia (Belardi, J.B., Ed.), Vol. 2, Universidad Nacional de la Patagonia Austral, Río Gallegos: p. 563-573. (in Spanish) ("The Rompecráneos: an Artifact Probably Intended for Hunting Pinnipeds, in the Coast of Continental Patagonia”)

Muñoz, A.S., Cruz, I. \& Caracotche, M.S. 2009, Cronología de la costa al sur del río Santa Cruz: Nuevas dataciones radiocarbónicas en Punta Entrada y Parque Nacional Monte León (provincia de Santa Cruz, Argentina). Magallania, 37(1): 19-38. (in Spanish) ("Chronology at the Coast South of Santa Cruz River: New Radiocarbon Dates Dates From Punta Entrada and Monte León National Park”) doi:10.4067/S071822442009000100016

Pérez-Álvarez, M. J., Carrasco, P., Sepúlveda, M. \& Quiñones, R.A. 2013, Comparison of behavioral patterns of South American sea lions between breeding and non-breeding seasons. Revista de Biología Marina y oceanografía, 48(1): 155-163. doi:10.4067/S0718-19572013000100013

Vaz-Ferreira, R., Vallejo, S. \& Huertas, M.D. 1984, Estudios comparativos de los etogramas de Otaria flavescens, Arctocephalus australis y otros otáridos (mammalia) Revista Brasileira de Zoología, 2(3): 171-180. (in Spanish) ("Comparative Studies of the Ethograms of Otaria flavescens, Arctocephalus australis and other Otarids (mammalia)”) doi:10.1590/S0101-81751987000200006 


\title{
Cazando en la costa: Una galería de imágenes de los rompecráneos
}

\author{
Daniela Soledad Cañete Mastrángelo \\ Consejo Nacional de Investigaciones Científicas y Técnicas, Instituto Nacional de Antropología y Pensamiento \\ Latinoamericano, 3 de Febrero 1378, CABA, Argentina. Email: danielasol.cm@gmail.com
}

\section{Resumen:}

Los rompecráneos son un tipo de artefacto lítico presuntamente vinculado a la captura de pinnípedos llevada a cabo a lo largo de la costa patagónica argentina durante tiempos prehistóricos. Investigaciones recientes han ofrecido información sobre su morfología pero hasta el momento siguen siendo poco estudiados. Para contrarrestar esta situación, en un trabajo anterior se abordó su rol en las técnicas de caza llevadas a cabo en la localidad arqueológica de Punta Entrada (Santa Cruz, Argentina). Con el objetivo de ampliar esta información, aquí se presenta una galería de imágenes de algunos rompecráneos recuperados en dicha localidad. Dos de estas piezas comparten características morfológicas pero fueron manufacturadas a partir de rocas diferentes. La tercera es más parecida a las bolas de boleadora pero su peso es superior al registrado para otros artefactos de su tipo en el resto de la Patagonia. Por tal motivo aquí no se la considera como tal. La importancia de estudiar estas piezas radica en que tienen el potencial de ofrecer información sobre el modo en que los humanos interactuaban con los diferentes recursos (bióticos y abióticos) en el pasado. De esta forma es posible desarrollar un mejor entendimiento sobre las conductas humanas.

Palabras clave: rompecráneos; tecnología lítica; Pinnípedos; Patagonia; herramientas de piedra pulida 